\title{
Early clinical predictors of diarrhea in the first fifteen days in dairy calves and their relationship with passive transfer status ${ }^{1)}$
}

\author{
ONUR TOPAL, HASAN BATMAZ
}

Department of Internal Medicine, Faculty of Veterinary Medicine, Bursa Uludag University, Görükle 16059, Bursa/Turkey

Topal O., Batmaz H.

Early clinical predictors of diarrhea in the first fifteen days in dairy calves and their relationship with passive transfer status

Summary

The neonatal period is very important in calves. It is extremely important to closely monitor newborn calves with good colostrum management during this period. In this study, the aim was to investigate whether the clinical parameters in the first $\mathbf{1 5}$ days after calves are born are correlated with diarrhea and whether those values are the early clinical predictors of the diarrhea that will occur in this period and also to investigate the correlation between diarrhea and the failure of transfer of passive immunity (FTPI). Eighty-two Holstein calves were used in the study. The calves were examined systemically every day and were scored according to a standard form. In the first 15 day period, $64.63 \%$ of the calves had diarrhea. In diarrheic calves, the most common findings on the previous day without diarrhea were fetid feces $(43.40 \%)$, changes in the consistency and color of feces, and a decrease in the temperature of the ears $(35.85 \%)$. According to non diarrheic calves, fetid feces $(P<0.01)$, changes in the consistency and color of feces, and nasal discharge were more common among diarrheic calves on the day before diarrhea $(p<0.001)$. The duration of diarrhea in calves with FTPI was longer than without FTPI. As a result, it is important for calves to be monitored daily in the first $\mathbf{1 5}$ days, looking for early signs of diarrhea in this period, namely fetid feces and changes in the consistency and the color of the feces. In addition, coexistence of any fecal changes with the decrease in the temperature of the ears may be clinical predictors of diarrhea. As a result of the daily monitoring of the calves, although the morbidity rate was high, none of the animals died.

Keywords: calf, clinical predictors, diarrhea, passive transfer immunity

Despite the fact that the neonatal period of calves comprises only a short time in their lives, this is the period of the highest incidence and mortality rates from diseases $(16,22,35)$. Calf diseases are very important in terms of both economic and animal welfare concerns because they cause calf deaths, high treatment costs and low efficiency in animal performance (19). The goals of raising calves are health, performance, substitute heifer production and profitability. Investments made in line with these objectives play an important role in ensuring the profitability for livestock owners and businesses economically. Therefore, it is of great importance to prevent illnesses and to improve calf recovery rates by making early diagnosis in this period (24).

During the neonatal period, colisepticemia, enterocolitis, rotavirus, coronavirus and cryptosporidiosis diarrhea are common in calves. Additionally, respira-

This study was financially supported by the Research Fund of Uludag University (Grant No: KUAP (V)-2015/9). tory tract diseases are a problem observed during this period $(13,17,21,25)$. As with other animals, young newborn calves have a high incidence of disease. During the first 15 days in the calves' lives, septicemia and diarrhea are the most common diseases, and it is the period when death is most commonly seen (1, $18,22)$. Determination of routine clinical parameters to monitor the health status of animals is a practical method for early diagnosis of diseases $(5,6)$. It has been observed that the daily monitoring of cows during the postpartum period, a critical period in dairy cattle, is of great importance for the future of the herd (5). It is known that daily assessments are extremely important for calves (23).

Passive transfer immunity is one of the most important factors affecting the health of the calves in the neonatal period $(11,27,34)$. The passage of immunoglobulins during pregnancy is minimal because the placenta of ruminants is epitheliochorial, so the 
newborn calves are hypogammaglobulinemic, and they need to consume colostrum as soon as possible after birth $(2,34)$. Calves that fail to receive this passive transfer are not protected against infectious diseases, and they have higher morbidity and mortality rates (3, 19, 23, 30).

Identification of the early signs of disease by monitoring clinical features daily and correlating the findings with failure of transfer of passive immunity (FTPI) values could be important in the first 15 days of the neonatal period, which is the critical period for the calves.

The aim of this study was to determine the early clinical predictors of diarrhea in calves and also to investigate the correlation between diarrhea and with FTPI.

\section{Material and methods}

Animals. The animals used in this study were 82 newborn Holstein calves at a farm. This study was performed in agreement with the guidelines for animal experimentations (UU Ethics Committee No: 2014-17/09). There were 43 male and 39 female calves. The average live birth weight was $40.07 \pm 0.75 \mathrm{~kg}$ for males and $38.08 \pm 0.82 \mathrm{~kg}$ for females. According to the farm management program, 2.5 liters of colostrum was offered to the calves by the employees within 3 hours after birth. They received 2.5 liters of freshly milked colostrum from their dams with nipple twice a day for the first three days of life. The calves were housed in individual boxes from the third day until one month. From the $3^{\text {rd }}$ day onwards, alfalfa hay, calf starter feed and water were given ad libitum. On average, 2.5 liters of milk were given twice a day for one month.

Daily clinical monitoring of the calves. General clinical examinations were performed by the same veterinarian between 8:00 am and 11:00 am every day for 15 days from the time they were born, and the data were recorded. The calves were evaluated according to the modified as in Table $1(5,6,22,28)$.

Collection of blood samples. Anticoagulant-free blood $(8-10 \mathrm{ml})$ was taken from the calves at the moment of birth

Tab. 1. Daily clinical monitoring form of calves

\begin{tabular}{|c|c|c|c|c|}
\hline Calf: & Ear number & Age ... day & Gender F/M & Age of mother \\
\hline & Clinical parameters & $\begin{array}{c}\text { Score } 1 \\
\text { Clinically healthy }\end{array}$ & $\begin{array}{c}\text { Score } 2 \\
\text { Suspicious health }\end{array}$ & $\begin{array}{c}\text { Score } 3 \\
\text { Disease symptoms }\end{array}$ \\
\hline \multirow{7}{*}{ Inspection findings } & posture & normal & low shoulder & $\begin{array}{c}\text { stagnant, back in roundback, } \\
\text { slightly raised tail }\end{array}$ \\
\hline & eyes looking & live & not alive & dull glance \\
\hline & suckling reflex & good & medium & weak-no \\
\hline & movements of the ears & active & decreased & no \\
\hline & position of the ears & upright & nearly upright, moderate & low \\
\hline & palpebral reflex & have & slight decrease & significantly reduced-lost \\
\hline & behavior, lethargy score & $0-1$ & 2 & $3-4$ \\
\hline \multirow{4}{*}{$\begin{array}{l}\text { Body temperature } \\
\text { parameters }\end{array}$} & rectal degree $\left({ }^{\circ} \mathrm{C}\right)$ & $38.5-39.4$ & $\begin{array}{l}38.0-38.5 \\
39.5-39.7\end{array}$ & $<38.0,>39.7$ \\
\hline & muzzle-nose temperature & at body temperature, warm & slight cold & cold \\
\hline & oral temperature & at body temperature, warm & slight cold & cold \\
\hline & ears temperature & at body temperature, warm & slight cold & cold \\
\hline \multirow{6}{*}{$\begin{array}{l}\text { Findings of systemic } \\
\text { circulation and dehydration }\end{array}$} & heart rate/min. & $90-130$ & $80-90,130-140$ & $<80,>140$ \\
\hline & enophtalmus & no & slight & moderate-severe \\
\hline & skin elasticity, sec. & 1 & $2-4$ & $>4$ \\
\hline & $\begin{array}{l}\text { color of conjunctiva and } \\
\text { mucous membranes }\end{array}$ & normal-pink & $\begin{array}{c}\text { slight } \\
\text { pale } \\
\text { hyperemic }\end{array}$ & $\begin{array}{l}\text { moderate-severe } \\
\text { pale, hyperemic } \\
\text { cyanotic }\end{array}$ \\
\hline & CFT, sec & $1-2$ & $>2$ & $>3$ \\
\hline & muzzle appearance & moist & slightly moist & dry \\
\hline \multirow{4}{*}{ Respiratory system findings } & lacrimation & no & slight & moderate-severe \\
\hline & nasal discharge & no & slight & moderate-severe \\
\hline & respiratory freq./min & $20-40$ & $16-20,40-44$ & $<16,>44$ \\
\hline & cough & no & induced single & $\begin{array}{l}\text { spontaneous-induced } \\
\text { multiple }\end{array}$ \\
\hline \multirow{3}{*}{ Digestive system findings } & feces consistency score & $1-2$ & 3 & 4 \\
\hline & the smell of feces & normal & slightly fetid & fetid \\
\hline & the color of feces & light brown & yellow & grey \\
\hline
\end{tabular}


(before the calves were given the colostrum) and then on the 1 st $\left(24^{\text {th }}\right.$ hour $), 3^{\text {rd }}$ and $7^{\text {th }}$ days after birth. Serum was obtained by centrifugation of the non-anticoagulated blood for 5 minutes at $5,000 \mathrm{rpm}$ and was stored in $-20^{\circ} \mathrm{C}$ in $2 \mathrm{ml}$ Eppendorf tubes until analysis.

Evaluation of passive transfer parameters. Immunoglobulin $\mathrm{G}$ ( $\mathrm{IgG}$ ) concentrations were measured from the obtained sera. The quantities of $\operatorname{IgG}$ in the study were determined by ELISA from serum samples (Bio-X Diagnostic Bovine ELISA Kit) at days 0, 1, 3, and 7. Calves with an $\operatorname{IgG}$ concentration $<10 \mathrm{~g} / \mathrm{L}$ were evaluated as FTPI (23-25). As this classification is based on references $(3,7)$, calves with an IgG value less than $5 \mathrm{~g} / \mathrm{L}$ have severe FTPI; calves with the range of 5-10 g/L have partial FTPI; calves with the range of $10-15 \mathrm{~g} / \mathrm{L}$ have sufficient passive transfer; good passive transfer is between $15-20 \mathrm{~g} / \mathrm{L}$; and calves with higher than $20 \mathrm{~g} / \mathrm{L}$ have very good passive transfer.

Statistical analysis. IBM SPSS 22.0 was used for statistical and descriptive analysis. Whether or not there was any difference between the values of each parameter on different days was examined by the Friedman test. If a difference was determined, Wilcoxon's test or a Paired Sample T-test was applied, according to whether the groups showed a normal distribution. Categorical variables were compared between diarrheic and non diarrheic groups with Pearson's chi-square test and Fisher's exact test. For all analysis, $\mathrm{P}<0.05$ was determined to be significant.

\section{Results and discussion}

In the first 15 days, diarrhea was observed in 53 $(64.63 \%)$ of the 82 newborn calves that received daily observation and clinical examination. However, there were no health problems in 20 calves. Pneumonia was observed in $6(7.31 \%)$ calves, including one of the animals with diarrhea; 3 calves $(3.65 \%)$ had septicemia; and 2 calves $(2.43 \%)$ had omphalophlebitis and diarrhea. In the first 15 days of the neonatal period, $64.63 \%$ of the diarrhea that occurred belonged to diarrhea cases as mentioned in the references $(18,31)$.

Tab. 2. Comparison of the most common findings before diarrhea with non diarrheic calves in first fifteen days

\begin{tabular}{|c|c|c|c|c|c|c|}
\hline Clinical examination finding & $\begin{array}{l}\text { Before the diarrhea }(n=53) / \\
\text { non-diarrheic }(n=220)^{*}\end{array}$ & $\begin{array}{c}\text { Score } 2 \\
(\mathrm{n})\end{array}$ & $\begin{array}{c}\text { Score } 3 \\
(n)\end{array}$ & $\begin{array}{c}\text { Score } 2+\text { Score } 3 \\
\text { (n) }\end{array}$ & $\begin{array}{c}\text { Score } 2+\text { Score } 3 \\
(\%)\end{array}$ & $P$ value \\
\hline \multirow{2}{*}{ Fetid feces } & diarrhea & 15 & 8 & 23 & 43.40 & \multirow{2}{*}{$<0.01$} \\
\hline & non-diarrheic & 32 & 13 & 45 & 20.45 & \\
\hline \multirow{2}{*}{$\begin{array}{l}\text { Change in the consistency } \\
\text { of the feces }\end{array}$} & diarrhea & 19 & - & 19 & 35.85 & \multirow{2}{*}{$<0.001$} \\
\hline & non-diarrheic & 30 & - & 30 & 13.63 & \\
\hline \multirow{2}{*}{ Change in feces color } & diarrhea & 16 & 3 & 19 & 35.85 & \multirow{2}{*}{$<0.001$} \\
\hline & non-diarrheic & 15 & 10 & 25 & 11.36 & \\
\hline \multirow{2}{*}{$\begin{array}{l}\text { Decrease in the temperature } \\
\text { of the ears }\end{array}$} & diarrhea & 15 & 4 & 19 & 35.85 & \multirow{2}{*}{0.147} \\
\hline & non-diarrheic & 41 & 16 & 57 & 25.90 & \\
\hline \multirow{2}{*}{ Increase of pulse } & diarrhea & 8 & 11 & 19 & 35.84 & \multirow{2}{*}{0.361} \\
\hline & non-diarrheic & 25 & 69 & 94 & 42.72 & \\
\hline \multirow{2}{*}{ Nasal discharge } & diarrhea & 11 & 4 & 15 & 28.30 & \multirow{2}{*}{$<0.001$} \\
\hline & non-diarrheic & 17 & 2 & 19 & 8.63 & \\
\hline \multirow{2}{*}{ Lacrimation } & diarrhea & 5 & 5 & 10 & 18.87 & \multirow{2}{*}{0.418} \\
\hline & non-diarrheic & 38 & 15 & 53 & 24.09 & \\
\hline \multirow{2}{*}{ Extension of CFT time } & diarrhea & 12 & - & 12 & 22.64 & \multirow{2}{*}{0.954} \\
\hline & non-diarrheic & 36 & 13 & 49 & 22.27 & \\
\hline \multirow{2}{*}{$\begin{array}{l}\text { Changing color in conjuctiva } \\
\text { and mucosa }\end{array}$} & diarrhea & 5 & 3 & 8 & 15.09 & \multirow{2}{*}{0.919} \\
\hline & non-diarrheic & 17 & 15 & 32 & 14.54 & \\
\hline \multirow{2}{*}{ Lethargy score 2} & diarrhea & 7 & 1 & 8 & 15.09 & \multirow{2}{*}{$<0.01$} \\
\hline & non-diarrheic & 9 & - & 9 & 4.09 & \\
\hline \multirow{2}{*}{ Decrease in suckling reflex } & diarrhea & 7 & - & 7 & 13.20 & \multirow{2}{*}{0.781} \\
\hline & non-diarrheic & 20 & 6 & 26 & 11.81 & \\
\hline \multirow{2}{*}{ Decrease in the skin elasticity } & diarrhea & 6 & - & 6 & 11.32 & \multirow{2}{*}{0.655} \\
\hline & non-diarrheic & 29 & 1 & 30 & 13.63 & \\
\hline \multirow{2}{*}{ Enophtalmus } & diarrhea & 6 & - & 6 & 11.32 & \multirow{2}{*}{0.776} \\
\hline & non-diarrheic & 21 & 1 & 22 & 10.00 & \\
\hline \multirow{2}{*}{ Change in posture position } & diarrhea & 6 & - & 6 & 11.32 & \multirow{2}{*}{0.095} \\
\hline & non-diarrheic & 9 & 1 & 10 & 4.54 & \\
\hline
\end{tabular}

Explanation: $* 11$ days (in 4-14 days) 11 days $\times 20$ calves $=220$ 
Thirty $(56.60 \%)$ of the 53 total diarrheic calves were males, and $23(43.40 \%)$ were females. Although the proportion of male calves with diarrhea was not much higher, male calves are heavier than females at birth, which is consistent with the suggestion in the literature (33) that the amount of colostrum male calves receive is insufficient compared to the amount females receive. In addition, the fact that the ratio of $\mathrm{IgG}$ in the male calves was lower than that in the females supports this view. Indeed, IgG levels were $13.01 \pm 1.82 \mathrm{~g} / \mathrm{L}$ in female animals with diarrhea on day 3 and $12.63 \pm 0.99 \mathrm{~g} / \mathrm{L}$ in male animals with diarrhea. As a matter of fact, the FTPI rate in a study was $16.0 \%$ in female calves and $22.6 \%$ in male calves (10).

The diarrhea was classified according to 3 different time periods: $0-5$ days, $6-10$ days and $11-15$ days. Two diarrhea cases were observed in the first period (only on the $5^{\text {th }}$ day) $(3.77 \%), 39$ in the $6-10$ day period $(73.58 \%)$ and 12 in the 11-15 day period (22.65\%). Notably, $73.58 \%$ of them were found between 6 and 10 days after birth, as indicated in other references $(14,21)$.

Clinical findings were seen the day before diarrhea occurred in more than $10 \%$ of 53 diarrheic calves, and the same clinical findings in calves without diarrhea are presented in Table 2. Other findings on the daily clinical monitoring form were not significant.

As diarrhea was seen between days 5 and 15 in the first 15-day period, the number of detections of the same clinical findings in days 4-14 in 20 calves without diarrhea was presented in Table 2 . As seen in Table 2, the most common findings on the previous day before diarrhea in the calves were the fetid feces $(43.40 \%)$, changes in the consistency and color of the feces and a decrease in the temperature of the ears $(35.85 \%)$. Compared with non diarrheic calves, fetid feces $(\mathrm{P}<0.01)$, changes in the consistency and color of the feces and nasal discharge were more common among diarrheic calves on the day before diarrhea $(\mathrm{P}<0.001)$. Comparing non diarrheic calves with the diarrheic calves, nasal discharge $(\mathrm{P}<0.001)$ and leth$\operatorname{argy}(\mathrm{P}<0.01)$ were observed more frequently the day before diarrhea. Changes in the feces are expected in the diarrheic calves the day before the onset of diarrhea. This may be a sign of a disrupted digestive activity (22). Comparing non diarrheic calves with the diarrheic calves, nasal discharge and lethargy were observed more frequently the day before diarrhea. Observation of more lethargy may be considered a sign of the onset of the disease (8). More nasal discharge may be due to the stimulation of the parasympathetic nerves (4).
Although postural changes on the day before diarrhea were not very common, this finding may be an important predictor when detected because it is close to statistical significance $(\mathrm{P}<0.095)$.

Table 3 shows the rate of co-occurrence of the most common findings the day before diarrhea. In diarrheic calves, only 6 had changes in all three feces scores, namely: the fetid of the feces, a change in the consistency of the feces, and a change in feces color, on the day before diarrhea. As shown in Table 3, 37.74\% of the cases had two of the 3 fecal changes present together. This suggests that the observation of two of the fecal changes increases the likelihood of diarrhea after one day. In addition, it was observed that it could be an important clinical predictor prior to diarrhea when the temperature of the ears decreased in combination with at least one fecal change $(\mathrm{P}<0.01)$. Since these calves have been observed for more than a year, the decrease in the temperature of the ears was not dependent solely on winter conditions.

The mean, minimum and maximum values of the $\mathrm{IgG}$ on different days are presented in Table 4 below. IgG level of the calves in the study was highest on the $3^{\text {rd }}$ day, which agrees with the references $(12,34)$ which indicate that Ig levels reached the highest value in 36-48 hours. It has even been stated that IgG reached the maximum concentration in 2-3 days of age (32).

Significant clinical findings were observed more frequently before diarrhea during the first 15-day period

Tab. 4. Mean, minimum and maximum values of IgG in different days

\begin{tabular}{|c|c|c|c|c|c|}
\hline & $\begin{array}{c}\text { Day 0 } \\
(\mathrm{n}=63)\end{array}$ & $\begin{array}{c}\text { Day 1 } \\
(\mathrm{n}=82)\end{array}$ & $\begin{array}{c}\text { Day 3 } \\
(\mathrm{n}=82)\end{array}$ & $\begin{array}{c}\text { Day 7 } \\
(\mathrm{n}=82)\end{array}$ \\
\hline \multirow{2}{*}{$\mathrm{IgG}$} & & $1.27 \pm 0.06^{\mathrm{a}}$ & $13.23 \pm 0.77^{\mathrm{b}}$ & $13.84 \pm 0.75^{\mathrm{b}}$ & $12.48 \pm 0.79^{\mathrm{c}}$ \\
$(\mathrm{g} / \mathrm{L})$ & $\min$ & 0.93 & 1.21 & 2.01 & 1.88 \\
& $\max$ & 3.50 & 45.7 & 36.51 & 47.27 \\
\hline
\end{tabular}

Explanation: $\mathrm{a}, \mathrm{b}, \mathrm{c}-$ means with different superscript letters differ significantly at $\mathrm{p} \leq 0,05$ 
Tab. 5. IgG concentrations on different days $(n=82)$

\begin{tabular}{|c|c|c|c|c|c|}
\hline Day & $\begin{array}{c}\text { Severe FTPI } \\
<5 \mathrm{~g} / \mathrm{L}\end{array}$ & $\begin{array}{c}\text { Partial FTPI } \\
5-10 \mathrm{~g} / \mathrm{L}\end{array}$ & $\begin{array}{c}\text { Sufficient } \\
\text { PT 10-15 g/L }\end{array}$ & $\begin{array}{c}\text { Good } \\
\text { PT 15-20 g/L }\end{array}$ & $\begin{array}{c}\text { Very Good } \\
\text { PT }>20 \mathrm{~g} / \mathrm{L}\end{array}$ \\
\hline 1 & $7(8.53 \%)$ & $17(21.25 \%)$ & $30(36.58 \%)$ & $19(23.17 \%)$ & $9(10.97 \%)$ \\
3 & $6(7.31 \%)$ & $18(21.95 \%)$ & $28(34.14 \%)$ & $19(23.17 \%)$ & $11(13.41 \%)$ \\
7 & $8(9.75 \%)$ & $24(29.26 \%)$ & $27(32.92 \%)$ & $17(20.73 \%)$ & $6(7.31 \%)$ \\
\hline
\end{tabular}

Explanations: PT - passive transfer; FTPI - failure of transfer of passive immunity

than in those without diarrhea. They were evaluated according to the presence of FTPI, but no significant difference was found. Table 5 shows that FTPI was $29.26 \%(8.53 \%+21.25 \%$ and $7.31 \%+21.95 \%)$ on the $1^{\text {st }}$ and $3^{\text {rd }}$ day and $39.02 \%(9.75 \%+29.26 \%)$ on the $7^{\text {th }}$ day. The FTPI was $29.26 \%$ on the $1^{\text {st }}$ and $3^{\text {rd }}$ day, when $\operatorname{IgG}<10 \mathrm{~g} / \mathrm{L}$ is taken as a criterion. While this ratio is higher than in some studies $(9,20)$, it agrees with the FTPI incidence reported in others $(3,8,34)$. The high FTPI ratio may be due to the insufficient amount of colostrum given (2.5 liters, 2 times per day for the first 3 days). In fact, higher volumes of colostrum are recommended $(26,34)$. While this ratio on the $7^{\text {th }}$ day is higher than on the $1^{\text {st }}$ and $3^{\text {rd }}$ days, this increase may be due to the tendency of Ig to decrease $(12,15)$. The high rate of diarrhea in the first 15 days in the calves may be the result of FTPI on the first and third days being as high as $29 \%$ and $26 \%$, respectively.

As noted in Table 6, it was observed that on the $1^{\text {st }}$ and $3^{\text {rd }}$ days diarrhea was seen in $79.16 \%$ of the calves with FTPI, whereas $60.34 \%$ of the calves without FTPI were diarrheic. The rate of diarrhea in calves with FTPI was high (79.16\%), as expected (7). In the calves without FTPI, the rate of diarrhea was also high $(60.34 \%)$. However, as shown in Table 6, the duration of diarrhea in calves with FTPI was much longer than without FPTI. For example, the duration of diarrhea in calves with severe FTPI was respectively $5.00 \pm 0.81,4.80$ \pm 0.96 and $4.28 \pm 0.74$ days on the $1^{\text {st }}$, $3^{\text {rd }}$ and $7^{\text {th }}$ days, whereas $2.08 \pm 0.22$, $1.67 \pm 0.22$ and $1.85 \pm 0.26$ days in calves with good PT levels. This may be because while FTPI plays an important role in the pathogenesis of diseases, it is not sufficient on its own, and other factors such as environmental and hygienic conditions are important in pathogenesis $(22,29)$. On the other hand, although the rate of diarrhea is high, the fact that most of the cases were mild may indicate that they were not exposed to serious infections. In fact, despite the high morbidity rate, the lack of deaths supports this explanation.

Daily inspections of the calves and early interventions, especially in the first 15 days, played their part in the absence of death, because the rate of diarrhea in the calves was very high.

In conclusion, it is important for calves to be monitored daily during the first 15 days, and early clinical predictors of diarrhea in this period are fetid feces and changes in the appearance and color of the feces. The coexistence of any two of these changes in fecal findings further increases the likelihood of diarrhea. In addition, coexistence of any fecal changes with decrease in the temperature of the ears may be clinical predictors of diarrhea. Because of daily monitoring of the calves, it was observed that there was no death, even though the morbidity rate was high. In addition, it was observed once again that the rate of diarrhea was higher in the calves with FTPI.

Tab. 6. Classification of diseased calves in the first 15 days according to IgG concentrations on different days $(n=82)$

\begin{tabular}{|c|c|c|c|c|c|}
\hline \multirow[b]{2}{*}{ Day } & \multicolumn{2}{|c|}{ FTPI } & \multicolumn{3}{|c|}{ Without FTPI } \\
\hline & $\begin{array}{l}\text { Severe FTPI } \\
(<5 \mathrm{~g} / \mathrm{L})\end{array}$ & $\begin{array}{l}\text { Partial FTPI } \\
(5-10 \mathrm{~g} / \mathrm{L})\end{array}$ & $\begin{array}{l}\text { Sufficient PT } \\
(10-15 \mathrm{~g} / \mathrm{L})\end{array}$ & $\begin{array}{c}\text { Good PT } \\
(15-20 \mathrm{~g} / \mathrm{L})\end{array}$ & $\begin{array}{l}\text { Very Good PT } \\
(>20 \mathrm{~g} / \mathrm{L})\end{array}$ \\
\hline Number of calves at $1^{\text {st }}$ day $\lg G$ level & 7 & 17 & 30 & 19 & 9 \\
\hline $\begin{array}{l}\text { Number and ratio of calves with diarrhea } \\
\text { and duration (day) of diarrhea }\end{array}$ & $\begin{array}{c}6 \\
85.71 \% \\
(5.00 \pm 0.81)\end{array}$ & $\begin{array}{c}13 \\
76.47 \% \\
(2.84 \pm 0.50)\end{array}$ & $\begin{array}{c}17 \\
56.66 \% \\
(2.11 \pm 0.25)\end{array}$ & $\begin{array}{c}12 \\
63.15 \% \\
(2.08 \pm 0.22)\end{array}$ & $\begin{array}{c}5 \\
55.55 \% \\
(2.20 \pm 0.33)\end{array}$ \\
\hline $\begin{array}{l}\text { Total number and the ratio of diarrheal } \\
\text { calves according to FTPI }\end{array}$ & \multicolumn{2}{|c|}{$\begin{array}{c}19 / 24 \\
79.16 \%\end{array}$} & \multicolumn{3}{|c|}{$\begin{array}{l}35 / 58 \\
60.34 \%\end{array}$} \\
\hline Number of calves at $3^{\text {rd day Ig } G \text { level }}$ & 6 & 18 & 28 & 19 & 11 \\
\hline $\begin{array}{l}\text { Number and ratio of calves with diarrhea } \\
\text { and duration (day) of diarrhea }\end{array}$ & $\begin{array}{c}5 \\
83.33 \% \\
(4.80 \pm 0.96)\end{array}$ & $\begin{array}{c}14 \\
77.77 \% \\
(3.50 \pm 0.43)\end{array}$ & $\begin{array}{c}19 \\
67.85 \% \\
(2.05 \pm 0.96)\end{array}$ & $\begin{array}{c}9 \\
47.36 \% \\
(1.67 \pm 0.22)\end{array}$ & $\begin{array}{c}6 \\
54.54 \% \\
(1.66 \pm 0.32)\end{array}$ \\
\hline $\begin{array}{l}\text { Total number and the ratio of diarrheal } \\
\text { calves according to FTPI }\end{array}$ & \multicolumn{2}{|c|}{$\begin{array}{c}19 / 24 \\
79.16 \%\end{array}$} & \multicolumn{3}{|c|}{$\begin{array}{c}34 / 58 \\
58.62 \%\end{array}$} \\
\hline Number of calves at $7^{\text {th }}$ day lgG level & 8 & 24 & 27 & 17 & 6 \\
\hline $\begin{array}{l}\text { Number and ratio of calves with diarrhea } \\
\text { and duration (day) of diarrhea }\end{array}$ & $\begin{array}{c}7 \\
87.50 \% \\
(4.28 \pm 0.74)\end{array}$ & $\begin{array}{c}17 \\
70.83 \% \\
(2.76 \pm 0.39)\end{array}$ & $\begin{array}{c}19 \\
70.37 \% \\
(2.21 \pm 0.31)\end{array}$ & $\begin{array}{c}7 \\
41.17 \% \\
(1.85 \pm 0.26)\end{array}$ & $\begin{array}{c}3 \\
60.00 \% \\
(2.33 \pm 0.33)\end{array}$ \\
\hline $\begin{array}{l}\text { Total number and the ratio of diarrheal } \\
\text { calves according to FTPI }\end{array}$ & \multicolumn{2}{|c|}{$\begin{array}{c}24 / 32 \\
75.00 \%\end{array}$} & \multicolumn{3}{|c|}{$\begin{array}{l}30 / 50 \\
60.00 \%\end{array}$} \\
\hline
\end{tabular}

Explanation: FTPI - failure of transfer of passive immunity 


\section{References}

1. Bartels C. J., Holzhauer M., Jorritsma R., Swart W. A., Lam T. J.: Prevalence, prediction and risk factors of enteropathogens in normal and non-normal faeces of young Dutch diary calves. Prev. Vet. Med. 2010, 93, 162-169.

2. Bartier A. L., Windeyer M. C., Doepel L.: Evaluation of on-farm tools for colostrum quality measurement. J. Dairy Sci. 2015, 98, 1878-1884.

3. Berge A. C., Besser T. E., Moore D. A., Sischo W. M.: Evaluation of the effects of oral colostrum supplementation during the first fourtheen days on the health and performance of preweaned calves. J. Dairy Sci. 2009, 92, 286-295.

4. Beule A. G.: Physiology and pathophysiology of respiratory mucosa of the nose and the paranasal sinuses. Laryngorhinootologie. 2010, 9, 15-34.

5. Bjimholt S., Muller K., Leiding C., Hoedemaker M., Bollwein H., Kaske M.: The daily clinical routine examination of dairy cows in the first two weeks after calving: Which parameters are decisive?. $8^{\text {th }}$ ECBHM Symposium Proceeding, 28-30 August 2013, Bern. p. 125

6. Charlton S. J.: Calf rearing guide. Context, Leicestershire. 2009, p. 100-124

7. Chigerwe M., Hagey J. V., Aly S. S.: Determination of neonatal serum immunoglobulin $\mathrm{G}$ concentrations associated with mortality during the first 4 months of life in dairy heifer calves. J. Dairy Res. 2015, 82, 400-406.

8. Cramer M. C., Ollivett T. L., Stanton A. L.: Associations of behavior-based measurements and clinical disease in preweaned, group-housed dairy calves. J. Dairy Sci. 2016, 99, 7334-7443.

9. Elsohaby I., McClure J. T., Keefe G. P.: Evaluation of digital and optical refractometers for assessing failure of transfer of passive immunity in dairy calves. J. Vet. Intern. Med. 2015, 29, 721-726.

10. Filteau V., Bouchard E., Fecteau G., Dutil L., DuTremblay D.: Health status and risk factors associated with failure of passive transfer of immunity in newborn beef calves in Quebec. Can. Vet. J. 2003, 44, 907-913.

11. Furman-Fratczak K., Rzasa A., Stefaniak T.: The influence of colostral immunoglobulin concentration in heifer calves' serum on their health and growth. J. Dairy Sci. 2011, 94, 5536-5543.

12. Godden S.: Colostrum management for dairy calves. Vet. Clin. N. Am-Food A 2008, 24, 19-39.

13. Gulliksen S. M., Jor E, Lie K. I., Hamnes I. S., Loken T., Akerstedt J., Osteras $O .:$ Enteropathogens and risk factors for diarrhea in Norwegian dairy calves. J. Dairy Sci. 2009, 92, 5057-5066.

14. Izzo M. M., Kirkland P. D., Mohler V. L., Perkins N. R., Gunn A. A., House $J$. K.: Prevalence major enteric pathogens in Australian dairy calves with diarrhoea. Aust. Vet. J. 2011, 89, 167-173.

15. Jezek J., Nemec M., Malovrht T., Klinkon M.: Indicators of passive immunity and health status of calves. Acta Vet-Beograd. 2010, 60, 513-523.

16. Leslie K.: Health and İmmun function in dairy calves. WCDS Adv. Dairy Technol. 2012, 24, 177-188.

17. Lorenz I., Earley B., Gilmore J., Hogan I., Kennedy E., More S. J.: Calf Health from birth to weaning III. housing and management of calf pneumonia. Ir. Vet. J. 2011, 64, 14.

18. Lorenz I., Fagan J., More S. J.: Calf health from birth to weaning. II. Management of diarrhoea in pre-weaned calves. Ir. Vet. J. 2011, 64, 9
19. Lorenz I., Mee J. F., Earley B., More S. J.: Calf health from birth to weaning. I. General aspects of disease prevention. Ir. Vet. J. 2011, 64, 10

20. Macfarlane J. A., Grove-White D. H., Royal M. D., Smith R. F.: Identification and quantification of factors affecting neonatal immunological transfer in dairy calves in the UK. Vet. Rec. 2015, 176, 625.

21. Mawly J. A., Grinberg A., Prattley D., Moffat J., Marshall J., French N.: Risk factors for neonatal calf diarrhoea and enteropathogen shedding in New Zealend dairy farms. Vet. J. 2015, 203, 155-260.

22. McGuirk S. M.: Disease management of dairy calves and heifers. Vet. Clin. N. Am. Food A. 2008, 24, 139-153.

23. McGuirk S. M.: Management of dairy calves from birth to weaning, [in:] Risco C. A., Retemal P. M. (ed.): Dairy production medicine. Wiley-Blackwell, Iowa 2011, p. 175-194.

24. McGuirk S. M., Peek S. F.: Timely diagnosis of dairy calf respiratory disease usin a standardized scoring system. Anim. Health Res. Rev. 2014, 15, 145-147.

25. Meganck V., Hoflack G., Piepers S., Opsomer G.: Evaluation of a protocol to reduce the incidenceof neonatal calf diarrhoea on dairy herds. Prev. Vet. Med. $2015,118,64-70$.

26. Osaka I., Matsui Y., Terada F.: Effect of mass of (Ig)G intake and ageat firs colostrum feeding on serum IgG concentration in Holstein calves. J. Dairy Sci. 2014, 97, 6608-6612.

27. Parish S. M., Tyler J. W., Besser T. E., Gay C. C., Krytenberg D.: Prediction of serum Ig Gl concentration in holstein calves using serum gamma glutamyltransferase activity. J. Vet. Intern. Med. 1997, 11, 344-347.

28. Poulsen K. P., McGuirk S. M.: Respiratory disease of the bovine neonate. Vet Clin. N. Am. Food A. 2009, 25, 121-137.

29. Quigley J.: Passive immunity in newborn calves. Adv. Dairy Technol. 2002, 14, 273-292.

30. Torsein M., Lindberg A., Sandgren C. H., Waller K. P., Törnquist M., Svensson C.: Risk factors for calf mortality in large Swedish dairy herds. Prev. Vet. Med. 2011, 99, 136-147.

31. Uhde F. L., Kaufmann T., Sager H., Albini S., Zanoni R., Schelling E., Meylam M.: Prevalence of four enteropathogens in the faeces of young dairrhoeic dairy calves in Switzerland. Vet. Rec. 2008, 163, 362-366.

32. Villarroel A., Miller T. B., Johnson E. D., Noyes K. R., Ward J. K.: Factors affecting serum total protein and immunoglobulin $\mathrm{G}$ concentration in replacement dairy calves. J. Adv. Dairy Res. 2013, 1, 2.

33. Vogels Z., Chuck G. M., Marton J. M.: Failure of transfer of passive immunity and agammaglobulinaemia in calves in south-west Victorian dairy herds prevalence and risk factors. Aust. Vet. J. 2013, 91,150-158.

34. Weaver D. M., Tyler J. W., Vanmetre D. C., Hostetler D. E., Barrington G. M. Passive transfer of colostral immunoglobulins in calves. J. Vet. Intern. Med. 2000, 14, 569-577.

35. Windeyer M. C., Lesilie K. E., Godden S. M., Hodgins D. C., Lissemore K. D., LeBlanc $S$. $J$.: Factors associated with morbidity, mortality and growth of dairy heifer calves up to 3 months of age. Prev. Vet. Med. 2014, 113, 231-240.

Corresponding author: Onur TOPAL, PhD, Bursa Uludag University, Faculty of Veterinary Medicine, Department of Internal Medicine, Görükle 16059, Bursa, Turkey; e-mail: onurtopal@uludag.edu.tr 